\title{
SISTEM AGRIBISNIS JAGUNG DI KECAMATAN ADILUWIH KABUPATEN PRINGSEWU
}

\author{
(Agribusiness System of Corn in Adiluwih Subdistrict of Pringsewu Regency)
}

Sita Virgiana, Bustanul Arifin, Ani Suryani

\begin{abstract}
Jurusan Agribisnis, Fakultas Pertanian, Universitas Lampung, Jl. Prof. Dr. Soemantri Brodjonegoro No. 1
Bandar Lampung 35145, e-mail: bustanul.arifin@fp.unila.ac.id
\end{abstract}

\begin{abstract}
This research aimed to know the procurement of corn production facilities, farm performance, corn marketing, supporting institutions and index of agribusiness system. This research was conducted in Adiluwih Subdistrict of Pringsewu Regency. The data were collected on March - April 2018 by survey method. The result of this research showed that the procurement of production facilities that did not accord to the criteria were price and quantity. The average income from the corn agribusiness system was Rp9,973,527.8/ha and it was profitable because the $R / C$ ratio was higher than one. Marketing of agribusiness systems was inefficient because its market was oligopsonic structure, farmers did not have the power to determine the price of corn and the profit margin ratio did not spread evenly. The supporting institutions in Adiluwih Subdistrict were farmer groups, extension agents, financial institutions, government policies, transportation and markets. All supporting institutions were available but not fully utilized by farmers. The supporting institutions which related to the agribusiness system were farmer groups, government policies and extension institutions. The agribusiness index in terms of production facilities has been good, while the agribusiness index in terms of farming and marketing performance has not been good. In general, the corn agribusiness index has notbeen good.
\end{abstract}

Key words: agribusiness index, agribusiness system, corn

\section{PENDAHULUAN}

Kegiatan pertanian secara luas mencakup tanaman pangan, hortikultura, perkebunan, perikanan, peternakan dan kehutanan. Komoditas yang penting dalam sektor pertanian salah satunya adalah tanaman pangan. Jagung adalah komoditas pangan yang dapat digunakan dalam memenuhi kebutuhan rumah tangga dalam kegiatan konsumsi yaitu sebagai bahan makan dan pakan bagi hewan ternak. Peran jagung lokal yang masih rendah dalam memenuhi kebutuhan industri pakan ternak mengakibatkan kebutuhan jagung tidak dapat terpenuhi sehingga menyebabkan impor jagung dan jagung sebagai komoditas dengan nilai impor yang tinggi yaitu sebesar 2,97 juta ton selama periode 2011-2015 (Kementerian Pertanian 2016).

Provinsi Lampung merupakan salah satu penyumbang produksi jagung di Indonesia. Meskipun bukan penghasil produksi jagung terbesar di Provinsi Lampung, namun jagung merupakan salah satu komoditas unggulan di Pringsewu. Kecamatan Adiluwih menjadi daerah penghasil jagung terluas dan produksi tertinggi di antara kecamatan lainnya yang ada di Pringsewu. Sebanyak 75 persen jagung di Kabupaten Pringsewu ditanam di Adiluwih (BPS Kabupaten
Pringsewu 2017). Sistem agribisnis jagung mengharuskan keterkaitan yang harmonis antara subsistem input, subsistem produksi, subsistem pengolahan hasil, pemasaran dan lembaga penunjang. Sistem agribisnis jagung di Kecamatan Adiluwih belum sepenuhnya berjalan dengan baik. Penggunaan sarana produksi oleh petani belum optimal yakni penggunaan benih dan pupuk yang tidak sesuai dengan anjuran dari pemerintah. Tidak sesuai anjuran yang dimaksud adalah penggunaan benih dan pupuk tidak sesuai dengan anjuran yang menyebabkan penggunaan sarana produksi menjadi lebih atau kurang dalam pemakaian. Produktivitas jagung di Kecamatan Adiluwih sebesar 5,0 ton/ha dan masih dapat ditingkatkan sampai dengan produksi potensial yaitu 10-12 ton/ha (Damiri 2017). Hasil survai menunjukkan bahwa produksi yang belum optimal dapat disebabkan oleh beberapa hal seperti terjadinya kekeringan karena pengairan mengandalkan dari hujan, serangan hama dan penyakit, curah hujan yang besar saat panen, rendahnya teknologi yang digunakan dan harga penjualan yang menurun saat panen.

Sistem pemasaran juga sangat berpengaruh terhadap ekonomi petani. Pada umumnya, diantara pelaku pemasaran jagung posisi petani adalah 
paling lemah karena adanya keterbatasan modal dan informasi yang diterima petani sehingga mendapatkan harga yang rendah. Selain itu, petani masih menghadapi ketidakpastian harga jual (Fitriani 2015). Banyaknya jumlah lembaga pemasaran yang terlibat juga akan mempengaruhi marjin pemasaran. Semakin tinggi marjin pemasaran maka akan semakin kecil pula persentasi harga yang diterima oleh petani (Firdaus 2008).

Lembaga penunjang yang ada yaitu gapoktan belum mampu mengumpulkan kekuatan petani dalam penetapan harga. Gapoktan sangat penting bagi petani karena dengan tergabung dalam gapoktan petani dapat diberikan bantuan berupa benih dan pupuk. Namun, gapoktan belum bisa membangun agroindustri pengolahan jagung dikarenakan faktor modal, sumber daya manusia, penguasaan teknologi dan tempat memasarkan hasil olahan. Kegiatan dalam sistem agribisnis memberikan keterkaitan antara satu subsistem dengan subsitem lainnya. Pengadaan sarana produksi atau input akan mempengaruhi besar atau kecilnya jumlah produksi yang menunjang kegiatan produksi (Oktaviana, Lestari dan Indriani 2016). Produk yang dihasilkan dari kegiatan usahatani akan memiliki keuntungan apabila dilakukan pengolahan dan pemasaran secara efisien. Berdasarkan latar belakang tersebut maka penelitian ini bertujuan untuk mengetahui pengadaan sarana produksi, kinerja usahatani, efisiensi pemasaran, serta indeks sistem agribisnis jagung di Kecamatan Adiluwih Kabupaten Pringsewu.

\section{METODE PENELITIAN}

Metode penelitian menggunakan metode survai. Data yang digunakan adalah data primer dan data sekunder. Penelitian dilakukan di Kecamatan Adiluwih Kabupaten Pringsewu. Pemilihan lokasi penelitian dilakukan secara sengaja (purposive). Pertimbangan dalam memilih lokasi penelitian adalah bahwa kecamatan tersebut merupakan sentra produksi jagung dengan produksi tertinggi serta dengan jumlah petani jagung terbanyak di Kabupaten Pringsewu serta komoditas unggulan di Kabupaten Pringsewu. Waktu penelitian dilakukan pada bulan Maret-April 2018. Populasi sasaran yang dipilih adalah semua petani yang tergabung dalam kelompok tani, memiliki pola tanam monokultur serta petani jagung peserta Upsus Pajale. Penentuan sampel menggunakan metode proporsional random sampling menggunakan rumus perhitungan Issac dan Michael dalam
Sugiarto et al. (2003). Jumlah populasi adalah 1.431 petani sehingga didapatkan jumlah sampel sebesar 73 petani. Jumlah sampel yang telah didapatkan diproporsikan menjadi dua desa yaitu Desa Srikaton sebesar 28 petani dan di Desa Waringinsari Timur sebesar 45 petani.

\section{Analisis Pengadaan Sarana Produksi}

Analisis ini digunakan untuk menganalisis sistem pengadaan sarana produksi agribisnis jagung di Kecamatan Adiluwih. Analisis ini dilakukan dengan pengamatan mengenai keadaaan lokasi penelitian meliputi pengadaan benih, pengadaan pupuk dan pestisida melalui 6T yaitu tepat jenis, waktu, harga, tempat, kualitas dan kuantitas.

\section{Analisis Kinerja Usahatani}

Pendapatan usahatani jagung dikaji berdasarkan dua indikator yaitu pendapatan usahatani jagung dan rasio R/C. Berikut adalah rumus pendapatan usahatani jagung (Shinta 2011).

$$
\begin{aligned}
& \pi=\mathrm{TR}-\mathrm{TC} \ldots \ldots \ldots \ldots \\
& \pi=(\mathrm{Y} . \mathrm{Py})-(\mathrm{FC}+\mathrm{VC}) \\
& \mathrm{R} / \mathrm{C}=\frac{\mathrm{TR}}{\mathrm{TC}} \ldots \ldots \ldots \ldots \ldots
\end{aligned}
$$

$$
\begin{aligned}
& \text { Keterangan: } \\
& \Pi \quad=\text { Pendapatan usahatani } \\
& \text { TR }=\text { Penerimaan usahatani } \\
& \mathrm{TC} \quad=\text { Biaya usahatani } \\
& \mathrm{Y} \quad=\text { Output atau produksi yang diperoleh } \\
& \mathrm{Py} \quad=\text { Price } \text { atau harga output } \\
& \mathrm{FC} \quad=\text { Fixed Cost } \text { atau biaya tetap } \\
& \mathrm{VC} \quad \text { Variable Cost atau biaya variabel }
\end{aligned}
$$

Apabila rasio yang didapatkan lebih dari satu maka usahatani yang dijalankan menguntungkan.

\section{Analisis Pemasaran}

Metode analisis pemasaran yang digunakan adalah deskriptif kualitatif yang digunakan untuk menganalisis struktur dan keragaan pasar, serta deskriptif kuantitatif untuk menganalisis keragaan pasar. Perhitungan analisis rasio keuntungan marjin dapat menggunakan rumus (Hasyim 2012).

$$
\mathrm{Mj}_{\mathrm{i}}=\mathrm{Ps}_{\mathrm{i}}-\mathrm{Pb}_{\mathrm{i}} \text { atau } \pi_{\mathrm{i}}=\mathrm{Mj}_{\mathrm{i}}-\mathrm{bt}_{\mathrm{i}}
$$

Penyebaran marjin dapat dilihat berdasarkan persentase keuntungan terhadap biaya pemasaran (Ratio Profit Margin/RPM) pada masing - masing 
lembaga pemasaran, dapat menggunakan rumus (Hasyim 2012).

$$
\mathrm{RPM}=\frac{\pi_{\mathrm{i}}}{\mathrm{bt}_{\mathrm{i}}}
$$

Keterangan:

$\mathrm{Mj}_{\mathrm{i}}=$ Marjin pemasaran tingkat ke- $\mathrm{i}$

$\mathrm{PS}_{\mathrm{i}}=$ Harga penjualan lembaga pemasaran tingkat ke-i

$\mathrm{Pb}_{\mathrm{i}}=$ Harga pembelian lembaga pemasaran tingkat ke-i

$\mathrm{bt}_{\mathrm{i}}=$ Biaya pemasaran lembaga pemasaran tingkat ke-i

$\pi_{\mathrm{i}}=$ Keuntungan lembaga pemasaran tingkat ke-i

Menurut Hasyim (2012) nilai RPM yang relatif menyebar merata pada berbagai tingkat pemasaran adalah cerminan dari sistem pemasaran yang efesien. Jika selisih RPM antar lembaga pemasaran sama dengan nol, maka pemasaran tersebut efisien. Sebaliknya, jika selisih RPM lembaga pemasaran tidak sama dengan nol, maka sistem pemasaran tersebut tidak efisien.

\section{Analisis Jasa Layanan Pendukung}

Metode deskriptif digunakan untuk mengetahui peran dan fungsi jasa layanan pendukung yaitu gapoktan, kebijakan pemerintah, lembaga penyuluhan, lembaga keuangan, kebijakan pemerintah, transportasi dan pasar dalam kelancaran sistem agribisnis jagung untuk mendukung dan melayani serta mengembangkan kegiatan dari setiap subsistem agribisnis.

\section{Indeks Sistem Agribisnis}

Indeks sistem agribisnis meliputi pengadaan sarana produksi, usahatani, pengolahan dan pemasaran. Pengukuran baik atau tidaknya sistem agribisnis jagung dapat menggunakan indeks agribisnis, dimana masing-masing indikator diberikan nilai seperti pada Tabel 1,2 dan 3. Pengukuran indeks agribisnis mengacu pada rumus Struges dalam Marhaendro (2013).

$$
\mathrm{RPM}=\frac{(\mathrm{X}-\mathrm{Y})}{\mathrm{k}}
$$

Keterangan:

$$
\begin{array}{ll}
\mathrm{Z} & =\text { Interval kelas } \\
\mathrm{X} & =\text { Jumlah nilai tertinggi } \\
\mathrm{Y} & =\text { Jumlah nilai terendah }
\end{array}
$$

\begin{tabular}{|c|c|}
\hline \multirow{4}{*}{$\begin{array}{c}\text { Indikator } \\
\text { - Pendapatan }\end{array}$} & Nilai \\
\hline & $0=$ rugi, apabila $\mathrm{R} / \mathrm{C}<1$ \\
\hline & $1=$ impas, apabila $\mathrm{R} / \mathrm{C}=1$ \\
\hline & $2=$ untung, apabila $\mathrm{R} / \mathrm{C}>1$ \\
\hline - Harga & $\begin{aligned} & 0= \text { lebih rendah dari musim } \\
& \text { sebelumnya }\end{aligned}$ \\
\hline & $1=$ lebih tinggi dari musim \\
\hline & Sebelumnya \\
\hline - Produktivitas & $\begin{array}{l}0=\text { kurang dari } 5,0 \text { ton } / \mathrm{ha} \\
1=\text { lebih dari } 5,0 \text { ton } / \text { ha }\end{array}$ \\
\hline - Penggunaan & $0=$ tidak sesuai anjuran \\
\hline benih & $1=$ sesuai anjuran \\
\hline - Penggunaan & $0=$ tidak sesuai anjuran \\
\hline urea & $1=$ sesuai anjuran \\
\hline - Penggunaan & $0=$ tidak sesuai anjuran \\
\hline phonska & $1=$ sesuai anjuran \\
\hline $\begin{array}{l}\text { - Penggunaan } \\
\text { organik }\end{array}$ & $\begin{array}{l}0=\text { tidak sesuai anjuran } \\
1=\text { sesuai anjuran }\end{array}$ \\
\hline
\end{tabular}

$\mathrm{k} \quad=$ Banyak kelas

Tabel 1. Indeks agribisnis segi sarana produksi

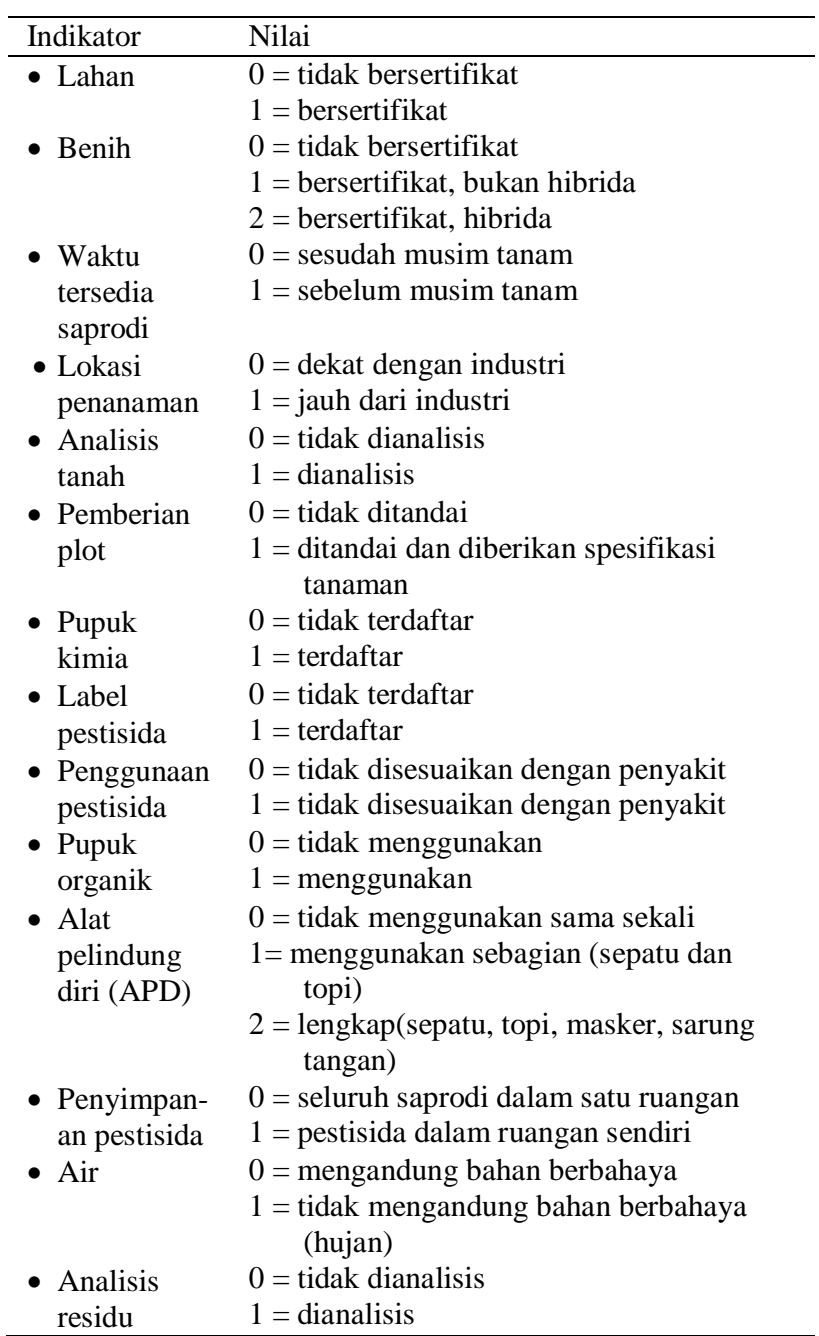

Tabel 2. Indeks agribisnis segi kinerja usahatani 
Tabel 3. Indeks agribisnis segi pemasaran

\begin{tabular}{|c|c|}
\hline Indikator & Nilai \\
\hline $\begin{array}{l}\text { - Waktu } \\
\text { pemanenan }\end{array}$ & $\begin{array}{c}0=\text { kurang dari } 100 \text { hari setelah } \\
\text { tanam }\end{array}$ \\
\hline & dari 100 hari setelah tanam \\
\hline - Pengangkut-a & $\begin{aligned} 0 & =\mathrm{leb} \\
1 & =\mathrm{kur}\end{aligned}$ \\
\hline $\begin{array}{l}\text { - Penggunaan } \\
\text { peralatan }\end{array}$ & $\begin{aligned} 0= & \text { tidak menggunakan alat pemanen } \\
& \text { (sarung tangan, karung, } \\
& \text { timbangan) }\end{aligned}$ \\
\hline & $\begin{aligned} 1= & \text { menggunakan alat pemanen } \\
& \text { (sarung tangan, karung, } \\
& \text { timbangan) }\end{aligned}$ \\
\hline $\begin{array}{l}\text { - Struktur } \\
\text { pasar }\end{array}$ & $\begin{array}{l}0=\text { tidak bersaing sempurna } \\
1=\text { bersaing sempurna }\end{array}$ \\
\hline $\begin{array}{l}\text { - Penentuan } \\
\text { harga }\end{array}$ & $\begin{aligned} 0= & \text { petani tidak dapat menentukan } \\
& \text { harga (tidak ada tawar menawar) } \\
1= & \text { petani dapat menentukan harga } \\
& \text { (tidak ada tawar menawar) }\end{aligned}$ \\
\hline $\begin{array}{l}\text { - Efisiens } \\
\text { pemasa }\end{array}$ & $\begin{array}{l}0=\text { belum efisien } \\
1=\text { sudah efisien }\end{array}$ \\
\hline
\end{tabular}

Indikator yang sudah diberikan nilai selanjutnya diklasifikasikan seperti pada persamaan 7. Indeks agribisnis pengadaan sarana produksi penilaiannya adalah $(0,00-8,00)$ belum baik dan $(8,01-16,00)$ baik. Indeks kinerja usahatani penilaiannya adalah (0,00-4,00) belum baik dan (4,01-8,00) baik. Indeks pemasaran penilaiannya adalah $(0,00-3,00)$ belum baik dan $(3,01-6,00)$ sudah baik. Penilaian seluruh indikator lalu ditimbang dan dapat dirumuskan seperti pada penelitian Soegiri (2009) pada persamaan 8. Apabila semakin mendekati nilai maksimum maka akan semakin baik sistem agribisnis jagung di Kecamatan Adilwuih.

$$
\bar{i}=\frac{\sum_{i=1}^{n} x_{i} w_{i}}{\sum_{i=1}^{n} w_{i}}
$$

\section{Keterangan:}

$\overline{\mathrm{i}}=$ Indeks rata - rata tertimbang

$\mathrm{x}_{\mathrm{i}}=$ Nilai indeks agribinis segi ke $\mathrm{i}$

$\mathrm{w}_{\mathrm{i}}=$ Bobot data ke $\mathrm{i}$

$\mathrm{n} \quad=$ Jumlah data

\section{HASIL DAN PEMBAHASAN}

\section{Analisis Pengadaan Sarana Produksi}

Pengadaan sarana produksi merupakan awal yang penting dalam mewujudkan kesuksesan sistem agribisnis. Menurut Oktaviana et al. (2016) tersedianya sarana produksi dari segi kualitas, kuantitas, waktu dan biaya yang tepat sangat dibutuhkan dalam menunjang kegiatan agribisnis. Hasil penelitian menunjukkan bahwa penggunaan sarana produksi benih, pupuk, pestisida, alat dan mesin serta tenaga kerja telah tepat jenis, kualitas, waktu, dan tempat. Benih jagung yang digunakan adalah hibrida yang sudah bersertifikat. Pupuk yang digunakan adalah urea, NPK Phonska serta organik. Penggunaan sarana produksi tersebut sudah memiliki izin produksi yang terletak pada label sehingga terjamin dan aman. Hasil penelitian menunjukkan bahwa terjadi kenaikan harga benih jagung. Kenaikan harga benih jagung tidak sesuai dengan harapan petani sehingga belum tepat harga. Penggunaan benih jagung telah sesuai anjuran dari Balai Besar Pengkajian dan Pengembangan Teknologi Pertanian (2016), sedangkan penggunaan pupuk urea yaitu $490,41 \mathrm{~kg} / \mathrm{ha}$ lebih tinggi dari anjuran (250-300 kg/ha) dan penggunaan pupuk phonska yaitu $224,98 \mathrm{~kg} / \mathrm{ha}$ masih kurang dari anjuran (250-350 kg/ha). Penggunaan pupuk kandang sebanyak 3.567,72 $\mathrm{kg} / \mathrm{ha}$ telah sesuai dengan anjuran yaitu 3.500$5.000 \mathrm{~kg} / \mathrm{ha}$. Berdasarkan hal tersebut maka petani belum menerapkan pemupukan yang seimbang.

\section{Analisis Kinerja Usahatani Jagung}

Kegiatan usahatani menghasilkan produk yaitu jagung yang dapat memberikan keuntungan. Data pada Tabel 4 menunjukkan bahwa penerimaan jagung sebesar Rp17.619.470,32/ha. Biaya tunai usahatani jagung yang dikeluarkan sebesar Rp5.116.011,74/ha. Biaya diperhitungkan yang dikeluarkan sebesar Rp2.529.930,71/ha. Total biaya usahatani jagung yang dikeluarkan adalah Rp7.645.942,44/ha, sehingga menghasilkan pendapatan total sebesar Rp9.973.527,88/ha.

Rasio R/C atas biaya tunai dan biaya total yang diperoleh adalah 3,44 dan 2,30 yang memiliki arti bahwa usahatani jagung yang diusahakan telah menguntungkan. Nilai $\mathrm{R} / \mathrm{C}$ atas biaya tunai sebesar 3,44 yang berarti bahwa setiap Rp1,00 biaya tunai yang dikeluarkan petani dapat menghasilkan penerimaan sebesar Rp3,44, sedangkan nilai $\mathrm{R} / \mathrm{C}$ atas biaya total 2,30 bahwa setiap Rp1,00 biaya total yang dikeluarkan petani dapat menghasilkan penerimaan sebesar Rp2,30. Hasil penelitian ini sesuai dengan penelitian yang dilakukan Dinata, Lestari dan Yanfika (2014) bahwa usahatani yang dijalankan menguntungkan dengan perolehan nilai $\mathrm{R} / \mathrm{C}$ atas biaya tunai adalah 2,80 dan nilai $\mathrm{R} / \mathrm{C}$ atas biaya total adalah 2,59. 
Tabel 4. Rata-rata penerimaan, biaya, pendapatan, dan nilai R/C usahatani Jagung per hektar di Kecamatan Adiluwih Kabupaten Pringsewu tahun 2018

\begin{tabular}{|c|c|c|c|c|}
\hline \multirow{2}{*}{ Uraian } & \multicolumn{4}{|c|}{ Usahatani Jagung } \\
\hline & Satuan & Jumlah & Harga $(\mathrm{Rp})$ & Nilai (Rp) \\
\hline \multicolumn{5}{|l|}{ Penerimaan } \\
\hline Produksi & $\mathrm{Kg}$ & $7.660,64$ & $2.300,00$ & $17.619 .470,32$ \\
\hline \multicolumn{5}{|l|}{ Biaya Produksi } \\
\hline \multicolumn{5}{|l|}{ I. Biaya Tunai } \\
\hline Benih & $\mathrm{Kg}$ & 17,41 & $74.479,45$ & $1.296 .418,59$ \\
\hline Pupuk Urea & $\mathrm{Kg}$ & 490,41 & $2.000,00$ & $980.821,92$ \\
\hline Pupuk NPK Phonska & $\mathrm{Kg}$ & 224,98 & $2.557,53$ & $575.386,81$ \\
\hline Pupuk Organik & $\mathrm{Kg}$ & $3.567,72$ & 332,88 & $1.187 .609,87$ \\
\hline Obat-obatan & $\mathrm{Rp}$ & & & $100.970,32$ \\
\hline TKLK & $\mathrm{Rp}$ & & & $885.573,63$ \\
\hline Sewa Lahan & $\mathrm{Rp}$ & & & $54.794,52$ \\
\hline PBB & $\mathrm{Rp}$ & & & $34.436,07$ \\
\hline Total Biaya Tunai & & & & $5.116 .011,74$ \\
\hline \multicolumn{5}{|l|}{ II. Biaya Diperhitungkan } \\
\hline Sewa Lahan & $\mathrm{Rp}$ & & & $1.958 .219,18$ \\
\hline TKDK & $\mathrm{Rp}$ & & & $533.918,38$ \\
\hline Penyusutan Alat & $\mathrm{Rp}$ & & & $37.793,15$ \\
\hline Total Biaya Diperhitungkan & & & & $2.529 .930,71$ \\
\hline II. Total Biaya & & & & $7.645 .942,44$ \\
\hline \multicolumn{5}{|l|}{ Pendapatan } \\
\hline I. Pendapatan Atas Biaya Tunai & & & & $12.503 .458,58$ \\
\hline II. Pendapatan Atas Biaya Total & & & & $9.973 .527,88$ \\
\hline R/C Atas Biaya Tunai & & & & 3,44 \\
\hline R/C Atas Biaya Total & & & & 2,30 \\
\hline
\end{tabular}

\section{Analisis Pemasaran}

\section{Struktur Pasar}

Lembaga pemasaran jagung terdiri dari petani yaitu sebagai produsen, pedagang pengumpul dan pabrik penerima jagung. Lembaga pemasaran jagung pada tingkat pertama berada pada struktur oligopsoni yaitu pasar tidak bersaing sempurna dikarenakan pasar terdiri dari beberapa pembeli (pedagang) yang menghadapi jumlah banyak penjual (petani). Jagung yang dipanen berbentuk tongkol. Jagung dipanen oleh tenaga kerja atas perintah pedagang pengumpul. Pada tingkat kedua pemasaran jagung struktur pasar juga oligopsoni dikarenakan 7 pedagang pengumpul yang menjual jagung ke 3 pabrik. Hasil penelitian menunjukkan bahwa semua lembaga pemasaran yaitu petani, pedagang pengumpul serta pabrik yang terlibat dalam agribisnis jagung bebas untuk keluar masuk suatu daerah untuk transaksi pembelian jagung. Tidak terdapat adanya pembagian wilayah dalam pembelian jagung oleh pedagang pengumpul dan pabrik.

\section{Perilaku Pasar}

Jagung yang telah siap dipanen langsung dijual kepada pedagang tanpa melakukan pengolahan pasca panen terlebih dahulu. Sistem transaksi pembelian biasanya para pedagang pengumpul sudah mengetahui kapan akan panen dan mereka akan langsung ke lahan petani, sehingga biaya angkut, karung dan tenaga kerja ditanggung oleh pedagang pengumpul. Proses pembentukan harga jagung pada lokasi penelitian ini adalah dari petani ke pedagang pengumpul sudah ketetapan dari pedagang, hal ini dikarenakan harga beli dari pabrik juga sudah ditetapkan saat pedagang akan menjualnya ke pabrik. Harga yang ditetapkan dari pabrik sering kali tidak sesuai dengan harapan para petani dan pedagang, tetapi tidak mempunyai pilihan lain. Saat hendak menjual jagung, di depan pabrik telah dituliskan harga jagung yang berlaku, sehingga apabila pedagang tidak menginginkan harga yang sesuai pedagang bisa tidak menjual jagung tersebut. Hal ini menyebabkan petani tidak bisa mendapatkan harga terbaik, dan untuk mempertahankan harga yang ditetapkan kualitas jagung juga harus baik agar harga jagung tidak turun. Sistem pembayaran yang terjadi adalah tunai. 


\section{Keragaan Pasar}

Saluran pemasaran jagung di Kecamatan Adiluwih dilalui oleh tiga lembaga sebagai berikut.

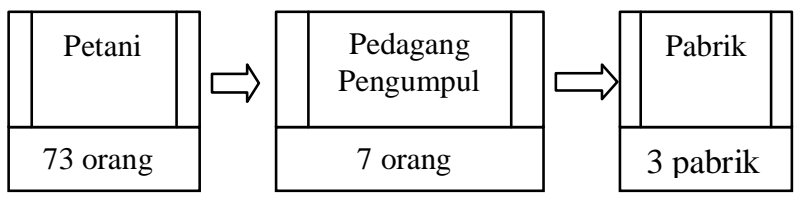

Gambar 1. Saluran pemasaran jagung di Kecamatan Adiluwih Kabupaten Pringsewu tahun 2018

Saluran pemasaran jagung di Kecamatan Adiluwih dilalui oleh tiga lembaga yaitu petani, pedagang pengumpul, dan pabrik (Gambar 1). Volume penjualan pedagang pengumpul ke pabrik pada musim tanam (MT) I sebesar $313.740 \mathrm{~kg}$ sedangkan pada MT II sebesar $287.880 \mathrm{~kg}$. Pedagang pengumpul ini tinggal satu desa dengan petani sehingga mudah dalam melakukan pemasaran. Rantai pemasaran jagung akan mempengaruhi marjin pemasaran yang dapat dilihat pada Tabel 5 dan Tabel 6.

Tabel 5 menunjukkan harga jual jagung dari petani ke pabrik memiliki perbedaan sebesar Rp $471,43 / \mathrm{kg}$ sehingga pangsa pasar yang didapatkan sebesar 82,99 persen dan tidak jauh dari pangsa pasar pabrik. Hal tersebut menunjukkan bahwa saluran pemasaran ini cukup baik dari sisi petani, karena semakin tinggi pangsa produsen akan semakin baik dari sisi petani. Pada hasil penelitian Ramadhani, Rahayu dan Setyowati (2014) memiliki perbedaan pangsa produsen yang didapatkan lebih besar yaitu 94,00 persen. Rasio profit marjin yang didapatkan dari hasil penelitian sebesar Rp1,15 yang memiliki arti bahwa setiap Rp1,00 yang dikeluarkan oleh pedagang maka akan mendapatkan keuntungan sebesar Rp1,15.

Pada MT II rasio profit marjin yang diterima sebesar Rp1,88 yang artinya setiap Rp1,00 yang dikeluarkan oleh pedagang akan mendapatkan keuntungan sebesar Rp1,88. Pada MTI harga jagung turun dikarenakan masuk pada musim panen besar yang mengakibatkan permintaan dari pabrik tetap tetapi penawaran dari pedagang meningkat. Pada musim tanam II harga jagung kembali normal dan keuntungan yang didapatkan pada setiap lembaga pemasaran menjadi lebih menguntungkan yang mengakibatkan pangsa produsen pada MT II lebih besar dibandingkan dengan MT I. Harga menjadi salah satu faktor dalam penerimaan keuntungan, setiap besarnya marjin keuntungan yang didapat akan mempengaruhi efisiensi pemasaran (Widiastuti dan Harisudin 2013).

\section{Lembaga Penunjang}

\section{Kelompok tani}

Kelompok tani sangat bermanfaat karena adanya distribusi pupuk bersubsidi bagi petani yang hanya akan diberikan kepada petani jika tergabung dalam kelompok tani. Gapoktan dapat memberikan pinjaman atau modal kepada petani apabila petani memerlukannya. Namun dalam agribisnis jagung petani belum memanfaatkan pinjaman kepada kelompok tani karena biaya yang masih dapat dijangkau. Lembaga penunjang ini yaitu kelompok tani sangat bermanfaat dan berkaitan bagi agribisnis jagung.

Tabel 5. Analisis marjin pemasaran musim tanam (MT) I jagung di Kecamatan Adiluwih Kabupaten Pringsewu tahun 2018

\begin{tabular}{clrrr}
\hline No. & \multicolumn{1}{c}{ Uraian } & $\begin{array}{c}\text { Marjin } \\
(\mathrm{Rp} / \mathrm{kg})\end{array}$ & $\begin{array}{c}\text { Pangsa } \\
(\%)\end{array}$ & $\begin{array}{l}\text { RPM } \\
(\%)\end{array}$ \\
\hline 1 & Harga jual Petani & $2.300,00$ & 82,99 & \\
2 & Pedagang & & & \\
& Pengumpul & & & 1,15 \\
& a. Harga beli & $2.300,00$ & 82,99 & \\
& b. Biaya total & 218,91 & 7,90 & \\
& Biaya Transportasi & 11,15 & 0,40 & \\
& Biaya Sopir & 10,98 & 0,40 & \\
& Biaya Tenaga Kerja & 157,14 & 5,67 & \\
& Biaya Karung & 39,64 & 1,43 & \\
& c. Marjin & 471,43 & 17,01 & \\
& d. Keuntungan & 252,52 & 9,11 & \\
& e. Harga jual & $2.771,43$ & 100,00 & \\
Pabrik & & & \\
& Harga Beli & $2.771,43$ & & \\
\hline
\end{tabular}

Tabel 6. Analisis marjin pemasaran musim tanam MT II jagung di Kecamatan Adiluwih Kabupaten Pringsewu tahun 2018

\begin{tabular}{clrrr}
\hline No. & \multicolumn{1}{c}{ Uraian } & $\begin{array}{c}\text { Marjin } \\
(\mathrm{Rp} / \mathrm{kg})\end{array}$ & $\begin{array}{c}\text { Pangsa } \\
(\%)\end{array}$ & $\begin{array}{c}\text { RPM } \\
(\%)\end{array}$ \\
\hline 1. & Harga jual Petani & $2.700,00$ & 80,77 & \\
2. & Pengumpul & & & 1,88 \\
& a. Harga beli & $2.700,00$ & 80,77 & \\
& b. Biaya total & 223,07 & 6,67 & \\
& Biaya Transportasi & 13,11 & 0,39 & \\
& Biaya Sopir & 12,44 & 0,37 & \\
& Biaya Tenaga Kerja & 157,14 & 4,70 & \\
& Biaya Karung & 40,38 & 1,21 & \\
& c. Marjin & 642,86 & 19,23 & \\
& d. Keuntungan & 419,79 & 12,56 & \\
& e. Harga jual & $3.342,86$ & & \\
3. Pabrik & & & \\
& Harga Beli & $3.342,86$ & & \\
\hline
\end{tabular}




\section{Lembaga penyuluhan}

Lembaga penyuluhan merupakan salah satu sarana yang diberikan pemerintah (BP3K) berupa PPL untuk dimanfaatkan petani mengenai masalah yang dihadapi petani. Lembaga penyuluhan yang terkait dalam kegiatan agribisnis jagung di Kecamatan Adiluwih yaitu dari pemerintah dan pihak swasta. Pemanfaatan PPL adalah mengenai penyuluhan penyakit, budidaya dan varietas baru. Para perusahaan sering melakukan pertemuan dalam rangka mempromosikan barang dagangannya. Adapun tugas lain PPL adalah menyusun Rencana Definitif Kebutuhan Kelompok (RDKK) pupuk bersubsidi yang dilakukan setiap menjelang akhir tahun untuk beberapa komoditas.

\section{Lembaga keuangan}

Lembaga keuangan formal pada lokasi penelitian salah satunya adalah Bank Rakyat Indonesia (BRI) Cabang Adiluwih. Pada musim tanam terakhir untuk komoditas jagung tidak ada petani yang meminjam pada bank. Hasil penelitian juga menunjukkan terdapat lembaga keuangan non formal antara lain gapoktan dan pedagang sarana produksi / toko pertanian. Petani dapat meminjam modal yang diperoleh dari uang kas gapoktan.

\section{Kebijakan pemerintah}

Salah satu peraturan pemerintah adalah petani harus tergabung dalam kelompok tani apabila ingin diberikan pupuk bersubisisdi serta bantuan lainnya. Pemberian bantuan selain dalam usahatani jagung juga mencakup usahatani lain seperti padi, cabai dan lain - lain. Melalui kelompok tani bantuan menjadi lebih mudah dalam didistribusikan. Kelompok tani juga mempemudah penyebaran informasi mengenai usahatani yang didapatkan dari peneliti.

\section{Transportasi}

Transportasi merupakan hal yang penting dalam kelancaran sistem agribisnis. Pemasaran jagung dilakukan oleh pembeli atau pedagang. Kendaraan yang digunakan dalam pengangkutan jagung biasanya adalah truk. Keseharian kendaraan yang sering di pakai petani adalah motor mengingat letak antara rumah dan ladang yang terbilang cukup jauh.

\section{Pasar}

Pasar merupakan salah satu lembaga dalam kelancaran sistem agribisnis. Petani di Desa Srikaton memiliki pasar yang sama dengan Desa Adiluwih yaitu Pasar Adiluwih. Pasar ini menyediakan berbagai kebutuhan rumah tangga dan terdapat beberapa kios pertanian. Bagi petani yang memilki rumah dekat pasar akan membeli saprodi dipasara, sedangkan yang jauh dari pasar akan membeli ke toko pertanian terdekat.

\section{Indeks Agribisnis}

\section{Sarana produksi}

Indeks agribisnis meliputi penggunaan sarana produksi yang digunakan seperti lahan, pupuk, dan pestisida. Indeks agribisnis segi sarana produksi yang didapatkan adalah 9,71 yang termasuk dalam kategori baik. Hal tersebut dikarenakan petani telah memiliki pengalaman dan pengetahuan yang cukup dalam berusahatani jagung.

\section{Kinerja usahatani}

Produktivitas, harga, pendapatan serta jumlah sarana produksi digunakan sebagai indikator pengukuran indeks. Indeks agribisnis segi kinerja usahatani yang didapat sebesar 3,42 dan termasuk ke dalam kategori belum baik dan menunjukkan bahwa penggunaan faktor produksi belum digunakan secara optimal. Menurut Widiyanti, Baga dan Suwarsinah (2016) penunjang dalam mencapai kinerja yang baik diantara nya adalah penentuan komoditas, ketersediaan sarana produksi seperti lahan, benih, pupuk dan tenaga kerja.

\section{Pemasaran}

Indeks agrbisnis jagung segi pemasaran yang didapatkan adalah 2,43 yang termasuk kedalam kategori belum baik. Indikator yang digunakan adalah waktu pemanenan, pengangkutan, penggunaan peralatan, struktur pasar dan efisiensi pemasaran. Hasil penelitian menunjukkan bahwa pemasaran jagung di lokasi penelitian belum efisien karena struktur pasar yang cenderung oligopsoni pada tingkat pertama dan kedua serta pangsa pasar yang belum menyebar secara merata. Selain itu, petani belum mampu menentukan harga jagung dan hanya sebagai penerima harga. Ketiga subsistem agribisnis tersebut memiliki nilai yang dapat dimasukkan kedalam rata-rata indeks agribisnis tertimbang. Berikut adalah perhitungan indeks agribisnis tertimbang. 


$$
\overline{\mathrm{i}}=\frac{(9,71 \times 16)+(3,42 \times 8)+(2,43 \times 6)}{30}=6,57
$$

Bila dilihat dari keseluruhan sistem agribisnis maka sistem agribisnis jagung belum berjalan dengan optimal. Hasil perhitungan menunjukkan bahwa indeks agribisnis yang diperoleh sebesar 6,57 dari nilai maksimal yaitu 11,86 atau sebesar 55,39 persen. Hal ini menunjukkan bahwa sistem agribisnis jagung di Kecamatan Adiluwih belum berjalan dengan baik.

\section{KESIMPULAN}

Berdasarkan hasil penelitian sistem agribisnis jagung telah memenuhi kriteria 6 tepat kecuali harga dan kuantitas. Kinerja usahatani juga telah baik dan menguntungkan. Pemasaran jagung belum efisien dikarenakan struktur pasar yang oligopsoni, belum adanya kekuatan penentuan harga jagung dari petani, nilai keuntungan marjin dan pangsa yang belum merata. Lembaga penunjang telah tersedia tetapi belum dimanfaatkan secara penuh oleh petani. Indeks agribisnis segi sarana produksi telah baik, sedangkan indeks agribisnis segi kinerja usahatani dan pemasaran belum baik. Keseluruhan sistem agribisnis jagung belum berjalan dengan baik.

\section{DAFTAR PUSTAKA}

BPS [Badan Pusat Statistik] Kabupaten Pringsewu. 2017. Kabupaten Pringsewu dalam Angka. Pringsewu. https://pringsewukab.bps.go.id/ backend/pdf_publikasi/Kabupaten-Pringsewu -Dalam-Angka-2017.pdf. [12 Oktober 2017].

Balai Besar Pengkajian dan Pengembangan Teknologi Pertanian. 2016. Teknologi Budidaya Jagung. Bandar Lampung.

Damiri. 2017. Stabilitas Produktivitas Jagung. Badan Penyuluhan dan Pengembangan Sumber Daya Manusia Pertanian. Kementerian Pertanian. http://cybex.Perta nian.go.id/teknologi/detail/2215/stabilitas-pro duktivitas-jagung. [10 November 2017].

Dinata AS, Lestari DAH dan Yanfika H. 2014. Pendapatan petani jagung anggota dan nonanggota Koperasi Tani Makmur Desa Natar Kabupaten Lampung Selatan. JIIA, Vol 2(3): 206-213. http://jurnal.fp.unila.ac.id/in dex.php/JIA/article/view/802. [28 Desember 2017].
Firdaus M. 2008. Manajemen Agribisnis. Bumi Aksara. Jakarta.

Fitriani. 2015. Penguatan kapasitas kelembagaan gapoktan melalui pembentukan koperasi pertanian. Masyarakat, Kebudayaan dan Politik, 28(2): 63-69. https://e-journal.unair. ac.id/mkp/article/download/2474/1821 _ [9 Maret 2018].

Hasyim AI. 2012. Tataniaga Pertanian. Universitas Lampung. Bandar Lampung.

Kementerian Pertanian. 2016. Outlook: Komoditas Pertanian Sub Sektor Tanaman Pangan Jagung. http://perpustakaan.bappe nas.go.id/lontar/file?file=digital/166967[_Kon ten_]-Konten\%20D1884.pdf. [9 Maret 2018].

Marhaendro ASD. 2013. Penyajian Data. http://staffnew.uny.ac.id/upload/132295850/p endidikan/PENYAJIAN+DATA.pdf. Oktober 2018].

Oktaviana E, Lestari DAH dan Indriani Y. 2016. Sistem agribisnis ayam kalkun di Desa

Sukoharjo Kabupaten Pringsewu Provinsi Lampung. JIIA, Vol 4(3): 262-268. http:// jurnal.fp.unila.ac.id/index.php/JIA/article/vie w/1500/1354. [11 Oktober 2017].

Ramadhani DK, Rahayu ES dan Setyowati. 2014. Analisis efisiensi pemasaran jagung (Zea mays) di Kabupaten Grobogan (Studi Kasus di Kecamatan Geyer). https://eprints.uns.ac.id /12428/. [02 Agustus 2018].

Shinta A. 2011. Ilmu Usahatani. UB Press. Malang. http://shinta.Lecture.ub.ac.id/files/ 2012/11/Ilmu-Usaha-Tani.pdf. [28 Desember 2017].

Soegiri H. 2009. Prospek indeks tendensi bisnis Jawa Timur. Jurnal Riset Ekonomi dan Bisnis, Vol 9(2): 66-79. http://ejournal.upn jatim.ac.id/index.php/ rebis/article/viewFile/ 30/ 20. [10 November 2018].

Sugiarto D, Siagian LT, Sunaryanto, dan Oetomo DS. 2003. Teknik Sampling. PT. Gramedia Pustaka Utama. Jakarta.

Widiastuti N dan Harisudin M. 2013. Saluran dan marjin pemasaran jagung di Kabupaten Grobogan. SEPA, 9 (2): 231 - 240. https:// eprints.uns.ac.id/1481/1/Saluran-dan-MarjinPemasaran-Jagung.pdf. [10 November 2017].

Widiyanti NMNZ, Baga LM dan Suwarsinah HK. 2016. Kinerja usahatani dan motivasi petani dalam penerapan inovasi benih jagung hibrida pada lahan kering di Kabupaten Lombok Timur. Jurnal Penyuluhan, 12(1): 31-42. http://journal.ipb.ac.id/index.php/jupe/article/ download/11317/8815. [04 Juni 2018]. 